\title{
Methods for studying root colonization by introduced beneficial bacteria
}

\author{
Elisa GAMALERO ${ }^{a *}$, Guido LinguA ${ }^{\mathrm{a}}$, Graziella BerTA ${ }^{\mathrm{a}}$, Philippe LeMANCEAU ${ }^{\mathrm{b}}$ \\ a Università del Piemonte Orientale “Amedeo Avogadro”, Department of Science and Advanced Technology, Corso Borsalino 54, 15100 Alessandria, Italy \\ b UMR "Microbiologie et Géochimie des Sols", INRA-CMSE, BP 86510, 21065 Dijon Cedex, France
}

(Received 24 October 2002; accepted 4 March 2003)

\begin{abstract}
Some free-living rhizobacteria are considered as potential biocontrol and plant growth-promoting agents. Successful application of beneficial bacteria as microbial inoculants requires their presence and activity at the appropriate level, but even more, at the right time and place. Various markers are described in the literature to differentiate introduced bacteria from indigenous microflora and to visualize them. These markers are presented together with the methods currently applied to quantifying bacterial densities and to characterizing the distribution of introduced bacteria. The methods of quantifying bacterial densities are either based on bacterial cultivation or not. Different types of microscopic observations, allowing the characterization of the bacterial distribution and location in the rhizosphere, are also described. The respective advantages and limitations of these markers and methods are discussed.
\end{abstract}

rhizosphere / bacterization / methodology

Résumé - Méthodes d'étude de la colonisation racinaire par des bactéries bénéfiques introduites. Certaines rhizobactéries libres sont considérées comme des agents potentiels de lutte biologique et de stimulation de la croissance des plantes. Le succès de leur application nécessite la présence et l'activité des bactéries à un niveau suffisamment élevé, mais également au bon moment et au bon endroit. Différents marqueurs permettant la différentiation des bactéries introduites de la microflore indigène ainsi que leur observation dans la rhizosphère, sont décrits dans la littérature. Ces marqueurs ainsi que les méthodes, appliqués pour quantifier la densité et pour caractériser la distribution des bactéries introduites, sont présentés. Les méthodes de quantification de la densité bactérienne sont basées ou non sur la culture des bactéries. Différentes méthodes d'observations microscopiques permettent de caractériser la distribution et la localisation bactérienne dans la rhizosphère. Les avantages et les inconvénients respectifs des marqueurs et des méthodes décrits sont discutés.

rhizosphère / bactérisation / méthodologie

\section{INTRODUCTION}

The rhizosphere was defined in 1904 by Hiltner [40] as being the volume of soil, influenced by the presence of living plant roots, whose extension may vary with soil type, plant species, age and other factors [34]. Plant roots release an enormous amount of root exudates that may represent up to $10-20 \%$ of the photosynthethates (see the review by C. Nguyen in the present issue), leading to a significant stimulation of the microbial density and activity. Specific populations are more favored than others in the rhizosphere due to the level of adequation of their metabolic activities with the composition of the root exudates. The structure and diversity of microbial populations in the rhizosphere thus differ significantly from those of soilborne populations [ 55 , $64,67]$. These quantitative and qualitative variations of the soilborne microflora are described as the rhizosphere effect. This rhizosphere effect varies according to the root exudate composition, which is affected by the plant physiology [26], the stage of plant development [115] and the position on the root system [57].

The microflora associated with the roots affect plant growth and health. Indeed, some bacterial populations are pathogenic, whereas others are beneficial. Beneficial rhizobacteria include both symbiotic and free-living microorganisms. Among the latter, special attention has been given to the fluorescent pseudomonad group. Positive effects on plant growth and health of inoculations of bacterial strains belonging to this

\footnotetext{
* Correspondence and reprints egamaler@unipmn.it
} 
bacterial group have been reported since the late ' $70 \mathrm{~s}[7,18$, $36,46,56,116]$. However, overall biological control of soilborne diseases achieved by microbial inoculants is often inconsistent [86]. This has been especially illustrated for fluorescent pseudomonads. This inconsistency has been partially associated with inefficient root colonization by the introduced bacteria [54, 116]. Indeed, a clear relationship has been established between suppression of the wheat root disease take-all and that of fusarium-wilts by different strains of fluorescent pseudomonads, and the densities of these bacteria in the corresponding host plants $[16,78]$. In order to make biological control more consistent, there is a need for a better knowledge of bacterial traits promoting rhizosphere competence.

Biocontrol of soilborne diseases is ascribed to microbial antagonism and/or to induced resistance of the host plant [25, 108]. Microbial antagonism results from the suppression of saprophytic growth of plant pathogens mediated by antibiotics and siderophores. The concentration of these metabolites in the rhizosphere is expected to be related to the density of active bacteria. Moreover, the synthesis of some of these metabolites (phenazines and pyoverdines) was demonstrated to be regulated by quorum-sensing [75, 94]. Besides the total bacterial density, which is related to the survival kinetics of the introduced strain, the antagonistic metabolites and thus the bacterial cells should be located at the infection courts of the soilborne pathogens. To summarize, the expression of the beneficial effects by the introduced bacteria requires their presence at a density high enough and at the time and location that are favorable for root infection by the pathogens.

The methods required for analyzing bacterial traits involved in the rhizosphere competence and plant-microbe interactions therefore must allow the quantification of bacterial density but also the characterization of the bacterial cell distribution and location. Moreover, these methods should take into account not only culturable, but also total bacterial cells, since the frequency of viable but non-culturable cells would vary according to the environmental conditions [100].

The aim of the present review is to present methods of quantification and characterization of the distribution along the roots of introduced bacteria in the soil and rhizosphere.

\section{MARKERS USED FOR TRACKING INTRODUCED BACTERIA}

Tracking bacteria introduced into complex environments such as soils requires the ability to discriminate them from the indigenous microflora. Markers used for that purpose should therefore fulfil several prerequisites. These markers should obviously be specific. This specificity must be checked in the environment in which bacteria are introduced. The markers should also be stable in soil and with time. The relative stability of the marker is required both to avoid its loss and/or its transfer to other bacteria. Since the aim of the markers is to perform ecological studies on the introduced bacteria, they should affect as little as possible the behavior of these bacteria. Surprisingly, there are few studies comparing the fitness of the marked and wild-type strains $[14,28,35,72,73,106]$. In the same way, since the perturbation of the system should be kept as low as possible, the expression of the marker should avoid substrate amendment. More generally, the markers chosen should be easy to track in a wide range of soils, and environmental conditions $\left(\mathrm{pO}_{2}, \mathrm{pH}\right.$, etc.) favorable for their expression should be considered [43].

In this section different markers are presented together with their properties.

\subsection{Serological markers}

The primary immunological tool used in environmental microbiology is the antibody. Immunoassays are analytical methods used to detect and/or quantify the antigen-antibody interaction. The conjugation of a signal molecule (fluorochromes, enzymes and radioisotopes) to the antibody is required to visualize the antigen-antibody interaction. Immunological techniques are relevant especially for the detection, enumeration and localization of introduced bacterial strains in the soil and rhizosphere. The critical aspect of serological methods is the specificity of the antibodies used. Polyclonal or monoclonal antibodies may be applied according to their specificity. Monoclonal antibodies are obviously more expensive to raise but are more specific. The specificity of the antibodies, especially polyclonal ones, should be checked to decrease the occurrence of possible cross-reactions. Usually, a high enough specificity may be obtained for fluorescent pseudomonad strains with polyclonal antibodies raised against membrane proteins [35].

\subsection{Molecular markers}

Various molecular markers such as antibiotic resistance [35, 53, 105], chromogenic ( $x y l \mathrm{E}$, gusA and lacZ) [48, 116], luminescent (luxAB and $l u c)[50,60,79,80,81,102]$ and fluorescent markers (gfp and unstable gfp) [13, 58, 71, 95] have been developed and widely applied to studying root colonization.

\subsubsection{Antibiotic resistance}

Antibiotic resistances have been widely used as markers in microbial ecology. Although various plasmids and transposons have been used [27, 69, 72, 76, 109], most of the studies on bacterial survival kinetics are based on the use of spontaneously occurring antibiotic-resistant mutants. Rifampicin resistance is commonly used as a marker to study survival kinetics of introduced bacteria in the rhizosphere [35, 68, 105]. Stability of rifampicin resistance was checked with Pseudomonas putida WCS358 in field conditions [35]. Kanamycin and streptomycin resistance obtained by Tn5 mutagenesis with the suicide plasmid method of Simon et al. [90] was also described as a possible marker [105]. The maintenance of Tn5 in the mutant JM218 was ascertained by comparing bacterial densities of this mutant in root suspensions, estimated by serology, with bacterial density estimated by plate count on King's B medium supplemented with kanamycin [53]. As stressed above, the level of resistance of the indigenous microflora to the antibiotic used as a marker must be determined in order to check the specificity of the marker used. As an example, Wilson et al. [118] have 
estimated that the background of naturally kanamycin-resistant bacteria in a Dutch soil was $2 \times 10^{4}$ cfu per gram.

Antibiotic resistance is often used for studies on survival kinetics of introduced bacteria $[35,68,76,105]$ since the corresponding detection method (plate counting, see Sect. 3.1) is quite sensitive, cost effective, reliable and easy to perform. However, possible genetic changes associated with chromosomal-mediated antibiotic resistance may affect several ecologically important traits $[14,28,63,91]$. Moreover, the use of antibiotic tagged bacteria carries with it the risk of contributing to the indesiderable spread of antibiotic resistance in nature [41].

\subsubsection{Chromogenic markers}

Several genes encoding metabolic enzymes have been used as markers to detect, quantify and localize introduced bacteria. The $x y l$ E gene encodes for a catechol 2,3-dioxygenase catalyzing the formation of hydroxymuconic acid that, reacting with a catechol, forms a yellow semialdehyde derivative. The gus $\mathrm{A}$ and lac $\mathrm{Z}$ genes encode for a $\beta$-glucuronidase and $\beta$ galactosidase, respectively: in the presence of the adequate substrates (5-bromo-4-chloro-3-indolyl- $\beta$-D-glucopyranoside and 5-bromo-4-chloro-3-indolyl-beta-D-galactopyranoside), they produce a blue pigment [41].

Although the use of these chromogenic markers is simple, not expensive and well defined, several disadvantages have been widely discussed [32, 43, 92]. For example, the $x y l$ E gene applicability is restricted due to inactivation of cathechol 2,3dioxygenase by oxygen [85]. The gus A and lacZ markers have limited application in soil because of the presence of high background $\left(10^{5} \mathrm{cfu} \cdot \mathrm{g}^{-1}\right.$ of soil) from the indigenous microflora $[33,118]$. Moreover, these chromogenic markers require substrates or reactives to be expressed or detected; the stability of these gene products is usually measured by hours or days [43].

\subsubsection{Luminescent markers: luxAB and luc genes}

Another very sensitive approach is the transfer of bioluminescence marker genes to bacteria, providing them with the capability of emitting light. Prokaryotic bioluminescence genes have been cloned from Vibrio fischeri and Vibrio harveyi $[9,31]$, while those eukaryotic (luc genes) have been cloned by the firefly Photinus pyralis [29]. The lux operon of $V$. fischeri includes five genes: two genes (lux $\mathrm{AB})$ encode the subunits of the luciferase enzyme and the other three (lux$\mathrm{CDE}$ ) encode enzymes involved in the synthesis of the aldehydic substrate (n-decanal) [43].

The requirement for molecular oxygen limits the use and the interpretations of this kind of physiological reporter system, but if oxygen is present, the monitoring of light may result in very useful information on bacterial activity and distribution in different environments such as the plant rhizosphere [70]. The minimum detection limit for fully active cells has been reported as 445 cells per gram of soil [81]. Although eukaryotic luc genes show some advantages in comparison with the prokaryotic counterpart (i.e. higher specificity and absence of background in native microflora), the substrate luciferin is expensive and sometimes not readily taken up by the cells. The stability of the gene product is usually measured by minutes or hours [43].

\subsubsection{Fluorescent markers: stable and unstable green fluorescent protein}

Another attractive marker system for monitoring bacterial cells in the environment is the green fluorescent protein (GFP). The GFP is a $27 \mathrm{KDa}$ polypeptide which converts the blue chemiluminescence of the $\mathrm{Ca}^{+2}$-sensitive photoprotein (aequorin from the jellyfish Aequorea victoria) into green light [20]. A series of red shifted GFP mutants, 20-35 times stronger than the wild type, with various excitation and emission wavelengths such as the ECFP (enhanced cyan), EGFP (enhanced green) and EYFP (enhanced yellow), have been recently developed [101].

The advantages and disadvantages of this marker have been extensively discussed by Errampalli et al. [32]. Some of the most relevant advantages are that GFP is extremely stable and resistant to proteases, is easily detectable, does not require exogenous substrate and allows the monitoring of single cells even in real time. Moreover, GFP is continuously synthesized and there is no background in indigenous bacterial populations. However, the interference of soil particles, the variability of GFP expression in different species, the inability to work in anaerobic conditions and the instability of the plasmid should be considered. In order to overcome the latest limitation and reduce the risk of a plasmid transfer to other microorganisms, bacterial strains used are preferentially chromosomally marked. For that purpose, several Tn 5 transposon suicide delivery vectors have been developed $[95,98]$. The stability of the GFP varies according to the variants and plasmid constructs in the range of hours or days [44, 95].

Recently, Andersen et al. [4] developed a new variant of GFP characterized by its short half-life. The unstable GFP has been constructed by the addition of a short peptide sequence to the C-terminal end of the intact GFP: this modification allows its degradation by bacterial endogenous proteases. Since the GFP produced during bacterial growth does not accumulate, it is possible to perform real-time analysis of the bacterial metabolic activity [58, 93]. However, different levels of proteases may be expressed depending on the microorganisms, the growth phase and environmental factors, and care must be applied in the interpretation of the results [44].

\subsubsection{Specific primers and oligonucleotidic probes}

Introduced bacteria can be monitored using primers or probes that allow amplification or hybridization of sequences which are strain-specific. Specific probes can be used to hybridize bacterial colonies after in vitro growth [117] or bacterial cells for in situ studies. Probes are usually covalently linked to a fluorochrome such as fluorescein, rhodamine, Texas red, Cy3 and Cy5 [3].

Specific sequences may be introduced by a genetic construction. As an example, a specific primer amplifying across $n p t I I-l a c Z$ junctions on the Tn5B20 construct was used to follow the survival kinetics in the soil and rhizosphere of the strain $P$. fluorescens $\mathrm{R} 2 \mathrm{f}$ tagged by the lacZ-nptII marker gene 
[109]. However, as stressed before, genetic constructs may affect the ecological behavior of bacterial strains.

Another strategy consists of identifying sequences specific to the strains in order to design primers and probes. Different approaches have been proposed to develop this identification. One is to compare homologous nucleic acid sequences of ribosomal RNA (rRNA) to sequences available in databases. Since rRNA are present in all living microorganisms in high copy number and are quite stable, oligonucleotidic probes can be applied [3]. They are either species-specific or even strainspecific in some cases $[5,24]$. Pseudomonas specific primer has been designed by Braun-Howland [15]. This PSMg primer was applied to describing the dynamic of indigenous populations of Pseudomonas in soil hot-spots [45] and to characterizing the succession of Pseudomonas on barley root in a perturbed environment [96]. Analysis of the $16 \mathrm{~S}$ rDNA of the Paenibacillus azotofixans strain with that of 2000 bacteria also enabled Rosado et al. [84] to identify the presence of three highly variable regions that were used to design primers for studying the kinetics of this bacterial strain in the soil and wheat rhizosphere. Another approach to defining primers and probes is (i) to characterize the diversity of populations belonging or not to the same group by Random Amplification of Polymorphic DNA-Polymerase Chain Reaction (RAPDPCR), in order (ii) to identify discriminating bands, then (iii) to pick them from the gel, and (iv) to re-amplify and test them for specificity.

Monitoring introduced bacteria on the basis of its specific RAPD-PCR pattern has also been proposed but is very timeconsuming $[21,51]$.

\section{METHODS TO QUANTIFY DENSITIES OF INTRODUCED BACTERIA}

Methods to quantify introduced bacteria can be classified into two major types depending upon whether they are based on the cultivation of the bacteria or not. Obviously, the culture-dependent methods will not allow the detection of viable but not culturable bacteria (VBNC). Since microorganisms introduced into soil can go through different processes (conversion to the non-culturable state and phase changes) doubts have been raised about the representativity of the view given by data yielded with culture-dependent methods of the real processes in soil. Despite this limitation, culture-dependent methods remain widely used, mainly because they are easy to apply. The culture-independent methods can provide a more complete picture of the kinetics of the total number of microbial cells [105]. However, the major limitation of these methods is that they may not allow differentiation between viable and not-viable cells.

In this section, major culture-dependent and culture-independent methods of microbial quantification in the rhizosphere are presented.

\subsection{Culture-dependent methods}

These methods are based on the suspension-dilution of soil and/or root samples and on inoculation of growing media (solid or liquid) with adequate dilutions. They require therefore the use of labeled strains (see Sects. 2.1 and 2.2). The culture-dependent methods differ according to the type of marker used giving the specificity to the growing media. This type of method is quite simple to perform, not too expensive and quite sensitive $\left(10^{2}-10^{3}\right.$ cfu per g), but labor-intensive and shows some limitations [44]. This type of method underestimates the number of bacteria present in soil or in the rhizosphere. Bacteria may remain physically attached to the soil particles, may be killed in the dilution medium or may fail to grow on growth media [47]. Some of them may remain aggregated even during the dilution process in such a way that a cfu may be originated by more than one cell. Suspensiondilution can either be plated on solid media or introduced into liquid media with various dilutions in order to determine from which dilution there is no more bacterial growth. This last method, named Most Probable Numbers (MPN), requires the use of probability tables to process data that contribute to reducing the sensitivity of the analysis compared with plating [61].

The most basic method consists of plating mutants resistant to antibiotics on solid growth medium supplemented with the corresponding antibiotic and with an anti-eucaryotic compound such as cycloheximide. This method is widely used, especially for survival kinetics of introduced bacteria and for competition studies between wild-type strains and mutants impaired in specific phenotypes $[67,68,72,106]$.

The sensitivity of this type of plating method may be significantly lowered by combining plating and serological approaches with the immunofluorescence colony-staining (IFC) technique. Detection limits as low as $20 \mathrm{cfu}$ of Erwinia spp. per gram of soil have been reported by Van Vuurde and Van der Wolf [111]. The IFC technique, developed by these authors, is based on the use of fluorescein isothiocyanate (FITC)-conjugated IgG antibodies specific to the introduced bacterial strain to discriminate target from non-target colonies. Bacterial colonies remain viable and IFC positive colonies can be subcultured to confirm their identity by other biochemical or molecular methods. Direct IFC has been used by several investigators $[52,53,63,77,110]$ to track and quantify bacterial strains introduced into soil or onto plants. Since the IFC does not require any alteration in the phenotype or genotype of the wild-type strain, this technique allows the comparison of an unaltered wild-type strain to a genetically modified derivative of the wild-type strain. The main restriction of direct IFC is the necessity of a good quality fluorescent conjugate against the target bacteria. However, outside the medical field, specific conjugates are usually not commercially available. For this reason, Veena and Van Vuurde [113] recently developed an indirect IFC using diluted specific antiserum and commercial conjugate to detect bacterial pathogens on tomato seeds. Indirect IFC is suitable for routine applications with facilities for fluorescence microscopy and does not require much expertise. As for any serological methods, the main limitation is the risk of false positive reactions due to cross-reacting bacteria.

Reporter genes may also be applied for culture-dependent methods. Lux-luc tagged bacteria can be detected and enumerated by plate counting, luminometry or scintillation counters and by imaging. Luminometry is an easy and sensitive method that has been applied to evaluating the density of luminescent 
bacteria on the root surface [8] and rhizosphere [81]. These two instruments are sensitive but they are not specifically designated for bioluminescence application [17]. Bioluminescent colonies can be counted directly by color photography (autophotography), by exposure to X-ray film, by direct microscopy with a CCD camera enhancement (imaging) or alternatively, if the amount of light emitted is high, it is possible to visualize them by eye [41].

Green fluorescence due to GFP-tagged bacteria can be observed in colonies cultured on agar media under a hand-held long-wave UV lamp. This is a simple and cheap way to enumerate colonies but the potential DNA damage of UV over time may be a limitation [32]. Fluorimetric detection of GFPlabeled bacteria is useful for screening or confirmation of cell growth. A detection limit of $10^{3}$ cells per ml of $P$. putida in soil has been reported by Burlage and Kuo [17]. Recently, Cassidy et al. developed a MPN method to evaluate cell density of GFP-marked Pseudomonas in the soil, rhizosphere and rhizoplane [19].

Finally, colonies grown on solid media can be hybridized with specific oligonucleotidic probes [117].

\subsection{Culture-independent methods}

Culture-independent methods can be distributed into three different categories: serological, molecular and cytological methods.

\subsubsection{Serological methods}

Among the serological methods, the enzyme-linked immunosorbent assay (ELISA) is a very sensitive immunoassay for the detection of antigens. ELISA is based on direct or indirect sandwich methods. The ELISA method has been used to study and quantify the external and internal root colonization of maize by two $P$. fluorescens strains [11] and the distribution of two diazotrophic enterobacterial strains, Pantoea agglomerans and Klebsiella pneumoniae, on cereal shoots and roots [82]. The ELISA method is quite sensitive $\left(10^{3}\right.$ cells per $\mathrm{ml}$ in pure cultures and $10^{4}-10^{5}$ cells per $g$ of soil) and associated with a standard curve relating the amount of signal given to the direct counts by microscopic enumeration, can provide quantitative information. Disadvantages are related to possible cross-reactivity and non-specific signal production.

\subsubsection{Molecular methods: detection of nucleic acids}

Detection methods based on nucleic acids extracted from the soil offer the possibility of monitoring specific bacterial genotypes (gene or genomic markers), providing a picture of the dynamics of total numbers of microbial cells [45]. The polymerase chain reaction (PCR), primarily used as a qualitative method to confirm the presence or absence of a specific DNA sequence, has been recently applied to obtaining quantitative information. Up to now, PCR has been the most sensitive method for detection of specific DNA in environmental samples; sensitivities of $1-100$ cells per gram of soil have been reported [42].

Before amplification, microbial DNA is extracted from soil. Various methods have been described for this extraction
[65]. All DNA extraction methods present potential bias depending on the soil properties (i.e. humic substances) [107]. The final goal of DNA extraction methods is to obtain DNA with a quality good enough for PCR amplification and for yielding consistent data.

Three PCR methods for quantification have been developed and applied to evaluating bacterial population in the soil or rhizosphere: the most probable number PCR (MPN-PCR), the competitive PCR (C-PCR) and quantitative PCR (Q-PCR).

In the case of MPN-PCR, the quantification of target sequences is based on the serial dilution of the PCR products in order to identify from which dilution the target sequence is no longer detectable by electrophoresis. The detectable limit of the product is calibrated by an external standard and the initial amount of the target molecules is estimated using the dilution factor of the positive sample. This method was first developed by Picard et al. with Agrobacterium tumefaciens and Frankia spp. [74]. Using this method, Picard et al. were able (i) to detect the $A$. tumefaciens strain when inocula ranged from $10^{3}$ to $10^{7}$ cells, and (ii) to estimate the indigenous populations of Frankia spp. at $0.2 \times 10^{5}$ genomes per gram of soil [74]. A detection limit of $10^{2} \mathrm{cfu}$ of Paenibacillus azotofixans per gram of rhizospheric soil was reported by Rosado et al. [84]. However, as indicated by Jansson and Leser [42], a limitation of the MPN-PCR method is the probabilistic evaluation, based on several dilutions and replicates, which contribute to reducing the precision of the estimation.

In C-PCR, a DNA fragment containing the same primer sequences (internal standard) as the target fragment is allowed to compete in the same tube with the target for primer binding and amplification. Experimentally, PCR reaction tubes containing the target samples are spiked with a dilution series of the competitor fragment. When the molar ratio of PCR products generated from the target and competitor is equal to one, the amount of the target is equal to the competitor. Since the amount of the competitor is known, the amount of the target can be determined. However, this technique is labor-intensive and its accuracy is dependent on an internal competitor, which must possess the same amplification efficiency as the target [42]. Thirup et al. [96] applied this type of PCR to studying the effects of $P$. fluorescens DR54 and the fungicide Imazalil on the succession of indigenous Pseudomonas spp. and Actinomyces on barley roots. Martin-Laurent et al. [66] have quantified with C-PCR the amount of the $a t z C$ gene known to be involved in atrazine mineralization in a soil treated with this herbicide.

Finally, Q-PCR is the direct measurement of the amount of products generated from different samples by a calibrated instrument. The initial amount of the target molecules in the samples is estimated by the determination of the PCR amplification efficiency defined by the amplification of a known amount of the same target (external standard). Q-PCR has certain limitations, such as accounting for the variation between samples during the reaction and the fact that quantification is only possible during the exponential phase of the amplification [42].

The major advantages of the PCR-based methods are their sensitivity and specificity. Theoretically, a single copy of the target nucleic acid sequence can be detected; normally, at least 
$10^{3}$ copies of the target are required for PCR methods in nucleic acids isolated from environmental samples. These methods allow one to take into consideration both cultivable and not cultivable organisms, but do not allow differentiation between viable and non-viable organisms.

\subsubsection{Cytological method: flow cytometry}

Flow cytometry is a cytological tool valid for evaluating root colonization by introduced bacteria. This instrument measures and analyzes the optical properties of hundreds of single cells per second, passing through a focused laser beam. As each cell or particle passes through the flow cytometer, it is monitored by forward scatter (detects each particle according to its size), side scatter (measures simultaneously the size and the shape of the particle) and fluorescence (evaluates the fluorescence intensity) detectors. Flow cytometry allows the detection and quantification of both the individual fluorescent cells within a population and the fluorescent intensity from more than one bacterial group. For environmental samples, bacteria from the particulate matter and an internal standard must be used to quantify the cell number [44]. A limitation of the technique is related to its low sensitivity due to the abundance of fluorescence particles present in most environmental samples. However, the assay is rapid and simple and thousands of cells can be analyzed in a short time, allowing the processing of the data by various statistical procedures.

Flow cytometry can be applied to evaluating the density and characterizing the kinetics of introduced bacteria tagged by fluorescent antibodies [23], GFP [98] and specific oligonucleotidic probes [96]. A detection limit of $10^{3}$ cells per ml has been recorded evaluating the density of fluorescent antibodytagged Xanthomonas campestris in Brassica oleracea [23], and of $3 \times 10^{4}$ cells per gram of dry soil in the characterization of the kinetics of the fluorescent oligonucleotidic probetagged Sphingomonas spp. strain 107 in soil [97].

The use of different dyes or fluorochrome provides an extremely powerful way to characterize the physiological state, activity or degree of viability of bacteria [37, 114], and thus to quantify by flow cytometry the viable and non-viable bacterial cells. Various criteria have been proposed to discriminate the viable from non-viable cells. Impermeability of the bacterial membrane to dyes is the basis of the dye exclusion test. Propidium iodide (PI) and other dyes characterized by the presence of quaternary ammonium groups and two or more positive charges, such as Sytox green, TO-PRO-1 and TOPRO-3, are membrane-impermeant. Cells retaining these dyes are usually considered as non-viable cells. Moreover, using simultaneously permeant (SYBR green) and non-permeant (PI) dyes makes possible the discrimination of cells with a compromised, slightly damaged or intact membrane [37]. The use of a membrane permeant substrate such as fluorescein diacetate (FDA) and 5-cyano-2,3-ditolyl tetrazolium chloride (CTC), that are cytoplasmic enzymatically cleaved to form a fluorescent impermeant product (fluorescein and formazan, respectively) allows the discrimination of cells with intact (retaining the product of the reaction) and damaged membranes (losing the product of the reaction) [112]. Membrane potential (MP) is the most used vitality parameter in microbial flow cytometry. A $100 \mathrm{mV}$ bacterial transmembrane electrical potential gradient, due to selective permeability and ionic transport, is usually reported. Variations in the MP measurement can be recorded using lypophilic charged dyes that can be accumulated or excluded by the cell [88].

\section{METHODS TO CHARACTERIZE DISTRIBUTION AND LOCALIZATION OF INTRODUCED BACTERIA}

Distribution and localization of introduced bacteria require the use of fluorescent antibodies, fluorescent markers and oligonucleotic probes (see Sects. 2.1, 2.2.4 and 2.2.5). These studies are sometimes only possible in gnotobiotic conditions.

Immunolocalization is based on the use of fluorescent signal molecules conjugated to the antibodies; the emission of fluorescent light indicates the presence of a specific antigen. The basic procedure consists of the reaction between a fluorescent specific antibody with the antigen attached to a slide, and of the observation of the sample using a fluorescence microscope. To enhance the signals and the specificity of the reaction, an indirect immunolocalization, using a fluorescent secondary antibody, is usually performed. Simultaneous localization of different antigens can be obtained using antibodies coupled to different fluorochromes. Immunolocalization has been successfully used to study root colonization. Examples include the analysis of the spatial competition between $P$. fluorescens Ag1 and Ralstonia eutropha (formerly Alcaligenes eutrophus) during barley root colonization [49], the cell distribution of $P$. fluorescens DF57 on barley roots [38], the autoecology of the biocontrol agent $P$. fluorescens $\mathrm{CHA} 0$ in the rhizosphere of different crops [100] and the endophytic colonization of spruce by Paenibacillus polymyxa (formerly Bacillus polymyxa) $\mathrm{Pw}-2 \mathrm{R}$ and $P$. fluorescens Sm3-RN [89]. Advantages of immunolocalization are the simplicity of its use and the short time required to obtain results. On the other hand, several problems, such as autofluorescence of the sample, non-specific staining, antigen instability and the inability to check viability have to be considered.

Lux genes have been widely used in the study of bacterial root colonization and activity [50, 60, 79, 83, 103], while luc genes have been only recently applied for monitoring activity of $P$. fluorescens $31 \mathrm{~K} 3$ in forest soil [12] and of Sinorhizobium arboris in the Acacia senegal rhizosphere [80].

GFP and its derivatives have been applied to characterizing the distribution of the biocontrol agent $P$. chlororaphis MA342 on barley seeds [99], the localization, the viability and the activity of $P$. fluorescens DR54 on the barley rhizosphere [71] and the colonization pattern of $P$. fluorescens WCS365 on tomato roots [13]. The use of different GFP color variants, allowing the simultaneous monitoring of multiple bacterial species, opens new perspectives in the study of complex microbial communities [13]. The visualization of GFP-tagged cells using microscopy assures a single cell detection level.

Fluorescent in situ hybridization (FISH) involves the use of fluorescence-labeled oligonucleotidic probes, constructed on the basis of the 16S rRNA sequence, to target rRNA within morphologically intact cells [2]. The FISH technique can be 


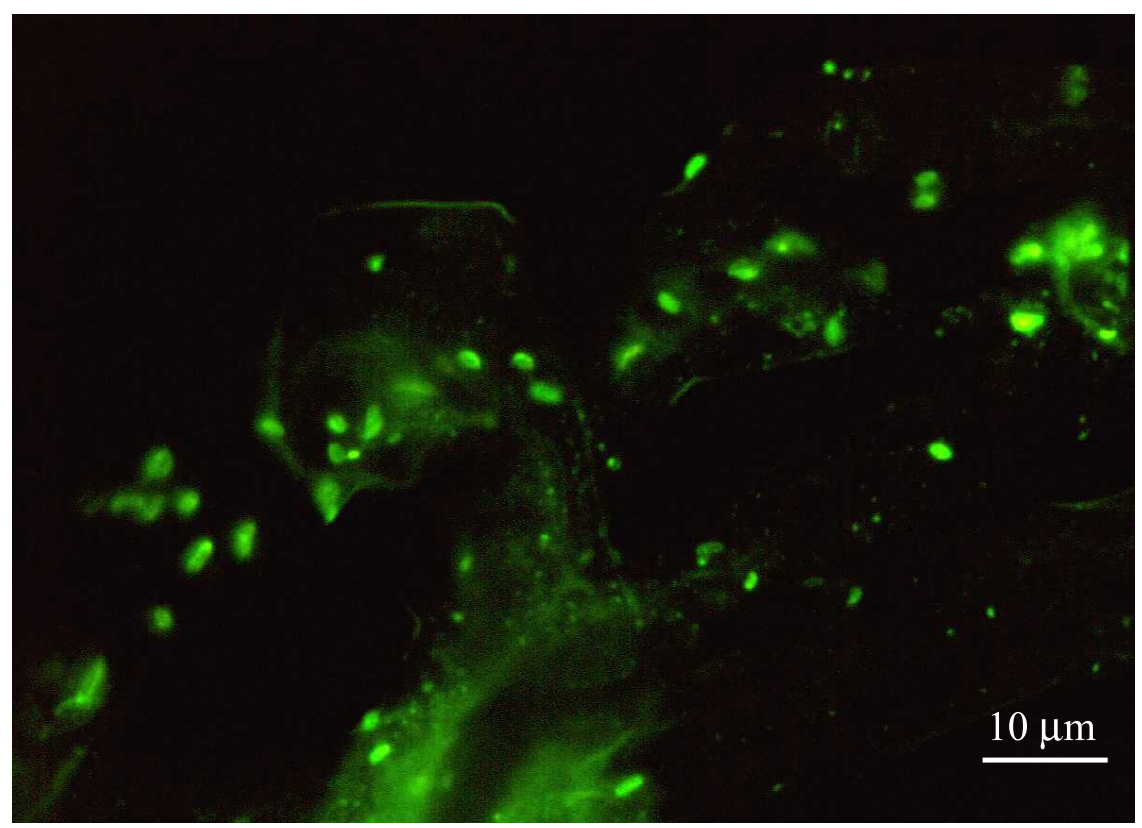

Figure 1. Epifluorescence image of FITC-antibody-labeled Pseudomonas fluorescens strain A6RI colonizing root hairs of a 7-day-old root of tomato grown in gnotobiotic conditions.

used to detect all bacterial cells, using a universal probe, or a single population, using a strain-specific probe. The in situ localization of Azospirillum brasilense in the wheat rhizosphere was described by Assmus et al. [5], the distribution of $P$. syringae and Rhodococcus fascians on the tomato root surface was characterized by Macnaughton et al. [62] and potato tissue infection by Ralstonia solanacearum was studied by Wullings et al. [119]. The in situ hybridization method is further detailed in the present issue by Schumpp et al. [87].

Bacteria marked by fluorescent antibodies, fluorescent markers and by oligonucleotic probes, can be detected by direct microscopy using an epifluorescent microscope with an adequate filter kit. The method is simple and the counts are rapid and precise, but the limit of detection is related to the field of view and to the matrix of the sample. Interfacing an epifluorescent microscope with a charged-coupled device (CCD) camera and image analysis software can enhance the sensitivity to a single cell level (Fig. 1). The main problem using direct microscopy is the high background of fluorescence coming from the root, the soil particles and the contaminants.

However, the recent development of confocal laser scanning microscopy (CLSM) has significantly reduced some of these limitations. CLSM is a powerful apparatus for visualizing with high resolution microbial cells labeled by fluorescent antibodies, GFP or oligonucleotidic probes. Because threedimensional views can be generated, CLSM readily lends itself to digital processing, by which images of thin optical sections can be reassembled into a composite, 3D image. The major advantage of CLSM is that the confocal imaging system allows the detection of signals only from the focused plane, limiting background fluorescence arising from materials such as plant tissue, soil particles or organic debris. Moreover, by using different fluorescence channels, CLSM allows the simultaneous detection of different bacterial populations and/ or secondary metabolites. For all these advantages, there is an increasing use of CLSM to localize introduced microorganisms on plant roots $[5,13,38,99]$. The limitation in the use of CLSM is the cost of the instrument.

Single-cell distribution of rhizobacteria along plant roots, grown in gnotobiotic conditions, can also be characterized by electron microscopy. The scanning electron microscope (SEM) has been widely used. For example, Chin-A-Woeng et al. [22] described by SEM the spatial-temporal tomato rhizosphere colonization pattern by the biocontrol agent P. fluorescens WCS365. More recently, Bacilio-Jimenez et al. [6] observed, by SEM analysis, the presence of two endophytic strains in rice seeds identified as Bacillus pumilus and Corynebacterium flavescens. The SEM provides an excellent resolution and allows exact localization of microorganisms in relation to the root structure (Fig. 2). However, sample preparation is expensive in time and needs care to avoid the production of artefacts. The transmission electron microscope (TEM) has also been widely applied, for example, to studying (i) the inter- and intracellular colonization of tomato roots by the biocontrol agent $P$. fluorescens WCS417r [30], and (ii) the cell colonization and infection thread formation in sugar cane roots by Acetobacter diazotrophicus [10]. Sample preparation for the TEM is much more time-consuming than for the SEM and requires other instruments (i.e. an ultramicrotome) to obtain sections with the adequate thickness.

Information regarding the internal root colonization by two different bacterial strains can be obtained by immunogold labeling. In addition, it has to be stressed that, both by SEM 


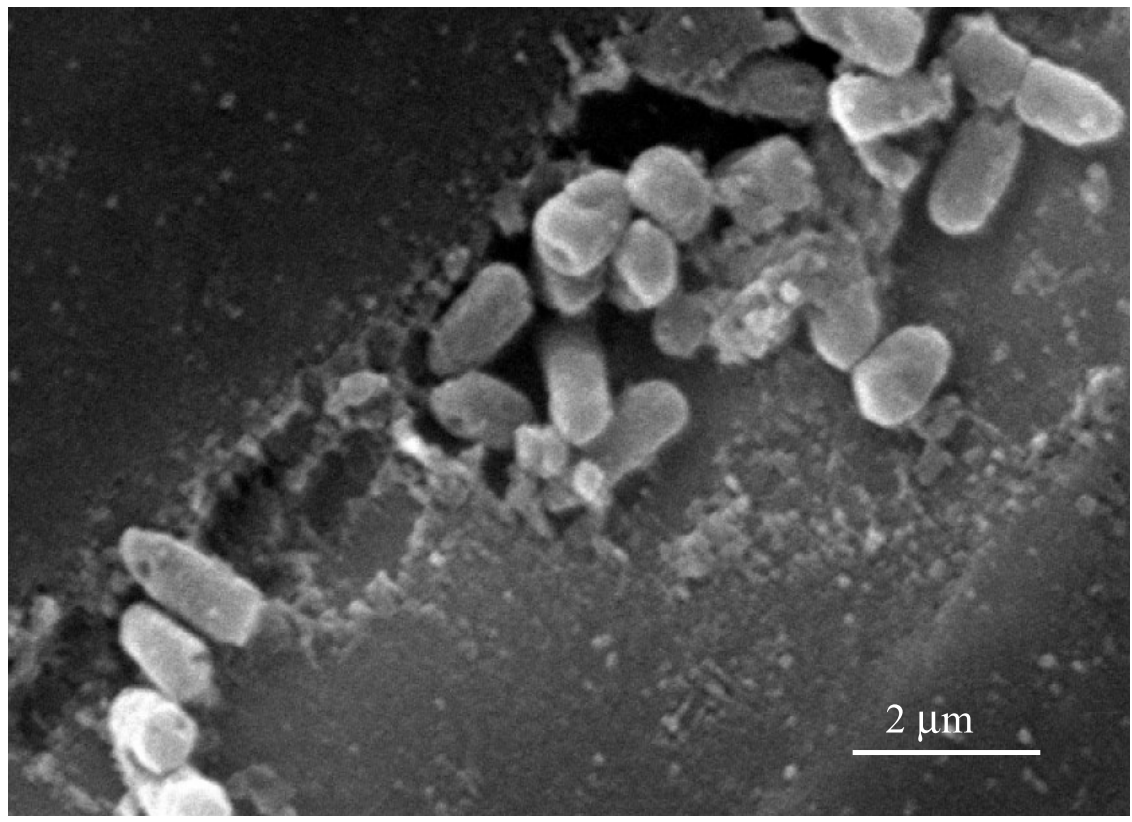

Figure 2. SEM image of Pseudomonas fluorescens A6RI colonizing the root surface of a 7-day-old root of tomato grown in gnotobiotic conditions.

and TEM, only very small root samples can be analyzed. To allow the investigation of a more general root bacterial distribution, electron microscopy should be combined with other methods [1].

\section{CONCLUSIONS AND PERSPECTIVES}

During the present review, different methodologies to quantify and localize introduced bacterial strains have been presented. These methods have their own advantages and limitations. Some only allow the quantification of cultivable bacteria, putting aside the so-called VBNC (culture-dependent methods). Others allow the quantification of the cultivable and non-cultivable cells of the introduced bacterial strain; however, they do not allow the discrimination of the viable and non-viable cells (immunofluorescence and PCR). Taking into consideration the limitations of both types of methods, a combination of culture-dependent methods and serological methods (IFC) or a combination of culture-dependent and molecular methods (colony hybridization) have been proposed. Combining colony counts of an antibiotic-resistant strain with the immunofluorescence technique has been successfully applied to monitoring the distribution and dynamic of bacteria in soil or on the root $[39,49]$.

Taking into account the advantages and the limitations of the different methods, a polyphasic approach based on the use of different enumeration methods (conventional plate counting, luminometry, fluorimetry, flow cytometry and quantitative PCR) has been proposed by Cassidy et al. [19] to discriminate the total number, and the number of viable and cultivable bacterial cells.
A polyphasic approach could also be proposed to both characterize the localization and the activity of the cells of the introduced bacterial strain. As an example, Lubeck et al. [59], applied the combination of fluorescent antibodies and FISH to studying sugar beet root localization of $P$. fluorescens DR54 by CLSM; this dual staining protocol allowed cellular activity to be recorded in both single cells and microcolonies during the bacterial establishment on the root. Similarly, Unge et al. [103] developed a dual $g f p$-luxAB marker system to monitor simultaneously the cell number and activity of specific bacterial populations. They recently applied this dual marker to characterizing the population size, the metabolic activity and the distribution pattern of $P$. fluorescens SBW25 along wheat roots by luminometry, flow cytometry and CLSM [104].

Over the last few years, there has been an increased interest in microscopic observations of the microflora in the rhizosphere [13, 38, 98], renewing the early studies of Foster [34]. This revival of interest is related to the progress made in the microscopy apparatus and in the molecular and serological markers.

In conclusion, different techniques combining multiple staining/tagging methods should provide more insight into the reciprocal interactions between the plant and the microorganisms in the rhizosphere and about the spatial-temporal colonization pattern and the physiological status of a microbial inoculant along the root.

Acknowledgments: The authors are grateful to Sylvie Mazurier and Christophe Mougel for the interesting and stimulating discussions and Anna Fusconi for the photo obtained by SEM. 


\section{REFERENCES}

[1] Achouak W., Heulin T., Villemin G., Balandreau J., Root colonization by symplasmata-forming Enterobacter agglomerans, FEMS Microbiol. Ecol. 13 (1994) 287-294.

[2] Amann R., Ludwig W., Ribosomal RNA-targeted nucleic acid probes for studies in microbial ecology, FEMS Microbiol. Rev. 24 (2000) 555-565.

[3] Amann R., Fuchs B., Behrens S., The identification of microorganisms by fluorescence in situ hybridization, Curr. Opin. Biotech. 12 (2001) 231-236.

[4] Andersen J.B., Sternberg C., Poulsen L.K., Bjørn S.P., Givskov M., Molin S., New unstable variants of green fluorescent protein for studies of transient gene expression in bacteria, Appl. Environ. Microbiol. 64 (1998) 2240-2246.

[5] Assmus B., Hutzler P., Kirchhof G., Amann R., Lawrence J.R., Hartmann A., In situ localization of Azospirillum brasilense in the rhizosphere of wheat with fluorescently labeled rRNA-targeted oligonucleotide probes and scanning confocal microscopy, Appl. Environ. Microbiol. 61 (1995) 1013-1019.

[6] Bacilio-Jiménez M., Aguilar-Flores S., del Valle M.V., Pérez A., Zepeda A., Zenteno E., Endophytic bacteria in rice seeds inhibit early colonization of roots by Azospirillum brasiliense, Soil Biol. Biochem. 33 (2001) 167-172.

[7] Bakker P.A.H.M., Bakker A.W., Marugg J.D., Weisbeek P.J., Schippers B., Bioassay for studying the role of siderophores in plant growth stimulation by fluorescent Pseudomonas spp. in short potato rotations, Soil Biol. Biochem. 19 (1987) 443-449.

[8] Beauchamp C.J., Kloepper J.W., Lewke P.A., Luminometric analyses of plant root colonization by bioluminescent pseudomonads, Can. J. Microbiol. 39 (1993) 434-441.

[9] Belas R., Mileham A., Cohn D., Hilmen M., Simon M., Silverman M., Bacterial bioluminescence: isolation and expression of the luciferase genes from Vibrio harveyi, Science 218 (1982) 791793.

[10] Bellone C.H., De Bellone S.D.V.C., Pedraza R.O., Monzon M.A., Cell colonization and infection thread formation in sugar cane roots by Acetobacter diazotrophicus, Soil Biol. Biochem. 29 (1997) 965-967.

[11] Benizri E., Schoeny A., Picard C., Courtade A., Guckert A., External and internal root colonization of maize by two Pseudomonas strains: enumeration by enzyme-linked immunosorbent assay (ELISA), Curr. Microbiol. 34 (1997) 297-302.

[12] Björklöf K., Jørgensen K.S., Applicability of non antibiotic resistance marker genes in ecological studies of introduced bacteria in forest soil, FEMS Microbiol. Ecol. 38 (2001) 179-188.

[13] Bloemberg G.V., Wijfjes A.H.M., Lamers G.E.M., Stuurman N., Lugtenberg B.J.J., Simultaneous imaging of Pseudomonas fluorescens WCS365 populations expressing three different autofluorescent proteins in the rhizosphere: new perspectives for studying microbial communities, Mol. Plant-Microbe Interact. 13 (2000) 1170-1176.

[14] Blot M., Hauer B., Monnet G., Tn5 bleomycin resistance gene confers improved survival growth advantage in Escherichia coli, Mol. Gen. Genet. 242 (1994) 595-601.

[15] Braun-Howland E.B., Vescio P.A., Nierzwicki-Bauer S.A., Use of a semplified cell blot technique and $16 \mathrm{~S}$ rRNA-directed probes for identification of common environmental isolates, Appl. Environ. Microbiol. 59 (1993) 3219-3224.

[16] Bull C.T., Weller D.M., Thomashow L.S., Relationship between root colonisation and suppression of Gaeumannomyces graminis var. tritici by Pseudomonas fluorescens strain 2-79, Phytopathology 81 (1991) 954-959.

[17] Burlage R.S., Kuo C.-T., Living biosensors for the management and manipulation of microbial consortia, Ann. Rev. Microbiol. 48 (1994) 291-309.

[18] Burr T.J., Schroth M.N., Suslow T., Increased potato yield by treatment of seed pieces with specific strain of Pseudomonas fluo- rescens and Pseudomonas putida, Phytopathology 68 (1978) 1377-1383.

[19] Cassidy M.B., Leung K.T., Lee H., Trevors J.T., Comparison of enumeration methods for culturable Pseudomonas fluorescens cells marked with green fluorescent protein, J. Microbiol. Methods 40 (2000) 135-145.

[20] Chalfie M., Tu Y., Euskirchen G., Ward W.W., Prasher D.C., Green fluorescent protein as a marker for gene expression, Science 263 (1994) 802-805.

[21] Chapon A., Guillerm A.Y., Delalande L., Lebreton L., Sarniguet A., Dominant colonization of wheat roots by Pseudomonas fluorescens $\mathrm{Pf} 29 \mathrm{~A}$ and selection of the indigenous microflora in the presence of the take-all fungus, Eur. J. Plant Pathol. 108 (2002) 449-459.

[22] Chin-A-Woeng T.F.C., de Priester W., Van der Bij A., Lugtenberg B.J.J., Description of the colonization of a gnotobiotic tomato rhizosphere by Pseudomonas fluorescens biocontrol strain WCS365, using scanning electron microscopy, Mol. PlantMicrobe Interact. 10 (1997) 79-86.

[23] Chitarra L.G., Langerak C.J., Bergervoet J.H.W., Van der Bulk R.W., Detection of the plant pathogenic bacterium Xanthomonas campestris pv. campestris in seed extracts of Brassica sp. applying fluorescent antibodies and flow cytometry, Cytom. 47 (2002) 118126.

[24] Christensen H., Hansen M., Sorensen J., Counting and size classification of active soil bacteria by fluorescence in situ hybridization and rRNA oligonucleotide probe, Appl. Environ. Microbiol. 65 (1999) 1753-1760.

[25] Cook R.J., Thomashow L.S., Weller D.M., Fujimoto D., Mazzola M., Bangera G., Kim D.-S., Molecular mechanisms of defence by rhizobacteria against root disease, Proc. Natl. Acad. Sci. USA 92 (1995) 4197-4201.

[26] De Leij F.A.A.M., Whipps J.M., Lynch J.M., The use of colony development for the characterization of the bacterial community in soil and on roots, Microb. Ecol. 27 (1994) 81-97.

[27] De Lorenzo V., Designing microbial systems for gene expression in the field, Trends Biotechnol. 12 (1994) 365-371.

[28] Devanas M.A., Rafaeli-Eshkol D., Stotzky G., Survival of plasmid containing strains of Escherichia coli in soil: effect of plasmid size and nutrients on survival of hosts and maintenance of plasmids, Curr. Microbiol. 13 (1986) 269-277.

[29] De Wet J.R., Wood K.V., Helinski D.R., De Luca M., Cloning of firefly luciferase cDNA and the expression of active luciferase in Escherichia coli, Proc. Natl. Acad. Sci. USA 82 (1985) 78707873.

[30] Duijff B.J., Gianinazzi-Pearson V., Lemanceau P., Involvement of outer membrane lipopolysaccharides in the endophytic colonization of tomato roots by biocontrol Pseudomonas fluorescens strain WCS417r, New. Phytol. 35 (1997) 325-334.

[31] Engebrecht J., Nealson K.H., Silverman M., Bacterial bioluminescence: isolation and genetic analysis of functions from Vibrio fischeri, Cell 32 (1983) 773-781.

[32] Errampalli D., Leung K., Cassidy M.B., Kostrzynska M., Blears M., Lee H., Trevors J.T., Applications of the green fluorescent protein as a molecular marker in environmental microorganisms, J. Appl. Microbiol. Methods 35 (1999) 187-199.

[33] Flemming C.A., Leung K.T., Lee H., Trevors J.T., Greer C.W., Survival of lux-lac marked biosurfactant producing Pseudomonas aeruginosa UG2L in soil monitored by non selective plating and PCR, Appl. Environ. Microbiol. 60 (1994) 1606-1613.

[34] Foster R.C., Microenvironments of soil microorganisms, Biol. Fertil. Soils 6 (1988) 189-203.

[35] Glandorf D.C.M., Brand I., Bakker P.A.H.M., Stability of rifampicin resistance as a marker for root colonization studies of Pseudomonas putida in field, Plant and Soil 147 (1992) 135-142.

[36] Glick B.R., The enhancement of plant growth by free-living bacteria, Can. J. Microbiol. 41 (1995) 109-117. 
[37] Gregori G., Citterio S., Ghiani R., Labra M., Sgorbati S., Brown S., Denis M., Resolution of viable and membrane compromised bacteria in freshwater and marine waters based on analytical flow cytometry and nucleic acid double staining, Appl. Environ. Microbiol. 67 (2001) 4662-4670.

[38] Hansen M., Kragelund L., Nybroe O., Sørensen J., Early colonization of barley roots by Pseudomonas fluorescens studied by immunofluorescence technique and confocal laser scanning microscopy, FEMS Microbiol. Ecol. 23 (1997) 353-360.

[39] Hase C., Mascher F., Moënne-Loccoz Y., Défago G., Nutrient deprivation and subsequent survival of biocontrol Pseudomonas fluorescens CHA0 in soil, Soil Biol. Biochem. 31 (1999) 11811188 .

[40] Hiltner L., Über neuere erfahrungen und problem auf dem gebeit der bodenbakteriologie und unter besonderer berucksichtigung der grundungung und brache, Arb. Dtsch. Landwirt. Ges. 98 (1904) $59-78$.

[41] Jansson J.K., Tracking genetically engineered microorganisms in nature, Curr. Opin. Biotechnol. 6 (1995) 275-283.

[42] Jansson J.K., Leser T., Quantitative PCR of environmental sample, in: Akkermans A.D.L., van Elsas J.D., de Bruijn F.J. (Eds.), Molecular Microbial Ecology Manual, Kluwer Academic Publishers, Dordrecht, The Netherlands 1996, pp. 1-19.

[43] Jansson J.K., Reporter genes for monitoring microbial cell activity and/or the environment. An opinion, MAREP (Marker/Reporter genes in microbial ecology): A concerted action: European Commission Biotechnology Programme, DGXII, Boras, Sweden, 1998.

[44] Jansson J.K., Molin S., Romantschuk M., Methods for monitoring genetically modified microorganisms (GMMs) in nature, NT Tech Report 455, 2000.

[45] Johnsen K., Enger O., Jacobsen C.S., Thirup L., Torsvik V., Quantitative selective PCR of 16 S ribosomal DNA correlates well with selective agar plating in describing population dynamics of indigenous Pseudomonas spp. in soil hot spot, Appl. Environ. Microbiol. 65 (1999) 1786-1789.

[46] Kloepper J.W., Schroth M.N., Plant growth promoting rhizobacteria and plant growth under gnotobiotic conditions, Phytopathology 71 (1981) 642-664.

[47] Kloepper J.W., Beauchamp C.J., A review of issues related to measuring colonization of plant roots by bacteria, Can. J. Microbiol. 38 (1992) 1219-1232.

[48] Kozaczuk M.M., Kopciñska J., Lotocka B., Golinowski W., Skorupska A., Infection of clover by plant growth promoting Pseudomonas fluorescens strain 267 and Rhizobium leguminosarum bv. trifolii studied by mTn5-gusA, Ant. van Leew. 78 (2000) 1-11.

[49] Kragelund L., Nybroe O., Competition between Pseudomonas fluorescens $\mathrm{Ag} 1$ and Alcaligenes eutrophus JMP134 (pJP4) during colonization of barley roots, FEMS Microbiol. Ecol. 20 (1996) $41-$ 51.

[50] Kragelund L., Hosbond C., Nybroe O., Distribution of metabolic activity and phosphate starvation response of lux-tagged Pseudomonas fluorescens reporter bacteria in the barley rhizosphere, Appl. Environ. Microbiol. 63 (1997) 4920-4928.

[51] Latour X., Philippot L., Corberand T., Lemanceau P., The establishment of an introduced community of fluorescent pseudomonads is affected both by the soil-type and the rhizosphere, FEMS Microbiol. Ecol. 30 (1999)163-170.

[52] Leeman M., Raaijmakers J.M., Bakker P.A.H.M., Schippers B., Immunofluorescence colony staining for monitoring pseudomonads introduced into soil, in: Beemster A.B.R., Bollen G.J., Gerlagh M., Ruissen M.T., Schippers B., Tempel A. (Eds.), Biotic Interactions and Soilborne diseases, Elsevier, Amsterdam, 1991, pp. 374 380 .

[53] Lemanceau P., Bakker P.A.H.M., De Kogel W.J., Alabouvette C., Schippers B., Effect of pseudobactin 358 produced by Pseudomonas putida WCS358 on suppression of fusarium wilt of car- nations by non pathogenic Fusarium oxysporum Fo47, Appl. Environ. Microbiol. 58 (1992) 2978-2982.

[54] Lemanceau P., Alabouvette C., Suppression of fusarium-wilts by fluorescent pseudomonads: mechanisms and applications, Biocontrol Sci. Technol. 3 (1993) 219-234.

[55] Lemanceau P., Corberand T., Gardan L., Latour X., Laguerre G., Boeufgras J.M., Alabouvette C., Effect of two plant species, flax (Linum usitatissimum L.) and tomato (Lycopersicon esculentum Mill.) on the diversity of soilborne populations of fluorescent Pseudomonads, Appl. Environ. Microbiol. 61 (1995) 1004-1012.

[56] Lifshitz R., Kloepper R.W., Kozlowsli M., Simonson C., Carlstone J., Tipping E.M., Zaleska I., Growth promotion of canola (rapeseed) seedlings by a strain of Pseudomonas putida under gnotobiotic conditions, Can. J. Microbiol. 33 (1987) 390395.

[57] Liljeroth E., Burgers S.L.G.E., Van Veen J.A., Changes in bacterial populations along the roots in wheat (Triticum aestivum L.) seedlings, Biol. Fertil. Soil 10 (1991) 276-280.

[58] Lowder M., Oliver D.J., The use of modified GFP as a reporter for metabolic activity in Pseudomonas putida, Microb. Ecol. 41 (2001) 310-313

[59] Lübeck P.S., Hansen M., Sørensen J., Simultaneous detection of the establishment of seed inoculated Pseudomonas fluorescens strain DR54 and native soil bacteria on sugar beet rot surfaces using fluorescence antibody and in situ hybridization techniques, FEMS Microbiol. Ecol. 33 (2000) 11-19.

[60] Ma W., Zalec K., Glick B.R., Biological activity and colonization pattern of the bioluminescence-labeled plant growth-promoting bacterium Kluyvera ascorbata SUD165/26, FEMS Microbiol. Ecol. 35 (2001) 137-144.

[61] MacCrady M.H., The numerical interpretation of fermentation tube results, J. Infect. Dis. 17 (1915) 183-212.

[62] Macnaughton S.J., Booth T., Embley T.M., O’Donnell A.G., Physical stabilization and confocal microscopy of bacteria on roots using 16S rRNA targeted, fluorescent-labeled oligonucleotide probes, J. Microbiol. Methods 26 (1996) 279-285.

[63] Mahaffee W.F., Bauske E.M., Van Vuurde J.W.L., Van der Wolf J.M., Van der Brink M., Kloepper J.W., Comparative analysis of antibiotic resistance, immunofluorescent colony staining, and a transgenic marker (bioluminescence) for monitoring the environmental fate of rhizobacterium, Appl. Environ. Microbiol. 63 (1997) 1617-1622.

[64] Maloney P.E., Van Bruggen A.H.C., Hu S., Bacterial community structure in relation to the carbon environment in lettuce and tomato rhizospheres and bulk soil, Microb. Ecol. 34 (1997) 109117.

[65] Martin-Laurent F., Philippot L., Hallet S., Chaussod R., Germon J.-C., Soulas G., Catroux G., DNA extraction from soils: old bias for new microbial diversity analysis methods, Appl. Environ. Microbiol. 67 (2001) 2354-2359.

[66] Martin-Laurent F., Piutti S., Hallet S., Wagschal I., Philippot L., Catroux G., Soulas G. Monitoring of atrazine treatment on soil bacterial, fungal, and atrazine degrading communities by quantitative competitive PCR, Pest Management Science, in press.

[67] Mavingui P., Laguerre G., Berge E., Heulin T., Genetic and phenotypic diversity of Bacillus polymyxa in soil and in the wheat rhizosphere, Appl. Environ. Microbiol. 58 (1992) 1894-1903.

[68] Mirleau P., Delorme S., Philippot L., Meyer J.M., Mazurier S., Lemanceau P., Fitness in soil and rhizosphere of Pseudomonas fluorescens $\mathrm{C} 7 \mathrm{R} 12$ compared with a C7R12 mutant affected in pyoverdine synthesis and uptake, FEMS Microbiol. Ecol. 34 (2000) 35-44.

[69] Mirleau P., Philippot L., Corberand T., Lemanceau P., Involvement of nitrate reductase and pyoverdine in competitiveness of Pseudomonas fluorescens C7R12 in soil, Appl. Environ. Microbiol. 67 (2001) 2627-2635. 
[70] Molin S., Givskov M., Application of molecular tools for in situ monitoring of bacterial growth activity, Environ. Microbiol. 1 (1999) 383-391.

[71] Normander B., Hendriksen N.B., Nybroe O., Green fluorescent protein marked Pseudomonas fluorescens: localization, viability and activity in the natural barley rhizosphere, Appl. Environ. Microbiol. 65 (1999) 4646-4651.

[72] Orvos D.R., Lacy G.H., Cairns J. Jr., Genetically engineered Erwinia carotovora: survival, intraspecific competition and effects upon selected bacterial genera, Appl. Environ. Microbiol. 56 (1990) 1689-1694.

[73] Philippot L., Clays-Josserand A., Lensi R., Use of Tn5 mutants to assess the role of dissimilatory nitrite reductase in the competitive abilities of two strains in soil, Appl. Environ. Microbiol. 61 (1995) 1426-1430.

[74] Picard C., Ponsonnet C., Paget E., Nesme X., Simonet P., Detection and enumeration of bacteria in soil by direct DNA extraction and polymerase chain reaction, Appl. Environ. Microbiol. 58 (1992) 2717-2722.

[75] Pierson L.S. III, Keppenne V.D., Wodd D.W., Phenazine antibiotic biosynthesis in Pseudomonas aureofaciens 30-84 is regulated by PhzR in response to cell density, J. Bacteriol. 176 (1994) 3966 3974.

[76] Prosser J.I., Molecular marker systems for detection of genetically engineered microorganisms in the environment, Microbiol. 140 (1994) 5-17.

[77] Raaijmakers J.M., Wilbert B., Punte H.L.M., Siderophore receptor PupA as a marker to monitor wild-type Pseudomonas putida WCS358 in natural environments, Appl. Environ. Microbiol. 60 (1994) 1184-1190.

[78] Raaijmakers J.M., Leeman M., Van Oorshot P., Van der Sluis L., Schippers B., Bakker P.A.H.M., Dose-response relationships in biological control of fusarium wilt of radish by Pseudomonas spp., Phytopathology 85 (1995) 1075-1081.

[79] Ramos C., Molina L., Mølbak L., Ramos J.L., Molin S., A bioluminescent derivative of Pseudomonas putida KT2440 for deliberate release into the environment, FEMS Microbiol. Ecol. 34 (2000) 91-102.

[80] Räsänen L.A., Elväng A.M., Jansson J., Lindström K., Effect of heat stress on cell activity and cell morphology of the tropical rhizobium Sinorhizobium arboris, FEMS Microbiol. Ecol. 34 (2001) 267-278.

[81] Rattray E.A.S., Prosser J.I., Glover L.A., Killham K., Characterization of rhizosphere colonization by luminescent Enterobacter cloacae at the population and single-cell levels, Appl. Environ. Microbiol. 61 (1995) 2950-2957.

[82] Remus R., Ruppel S., Jacob H.J., Hecht-Bucholz C., Merbach W., Colonization behavior of two enterobacterial strains on cereals, Biol. Fertil. Soils 30 (2000) 550-557.

[83] Roberts D.P., Kobayashi D.Y., Dery P.D., Short N.M., An image analysis method for determination of spatial colonization patterns of bacteria in plant rhizosphere, Appl. Microbiol. Biotechnol. 51 (1999) 653-658.

[84] Rosado A.S., Seldin L., Wolters A.C., Van Elsas J.D., Quantitative 16S rDNA-targeted polymerase chain reaction and oligonucleotide hybridization for the detection of Paenibacillus azotofixans in soil and the wheat rhizosphere, FEMS Microbiol. Ecol. 19 (1996) 153-164.

[85] Saunders J.R., Pickup R.W., Morgan J.A., Winstanley C., Saunders V.A., $X y l E$ as a marker for microorganisms, in: Akkermans A.D.L., Van Elsas J.D., de Bruijn F.J. (Eds.), Molecular Ecology Manual, Kluwer Academic Publisher.

[86] Schippers B., Bakker A.W., Bakker P.A.H.M., Interactions of deleterious and beneficial rhizospheric microorganisms and the effect on cropping practices, Ann. Rev. Phytopathol. 25 (1987) 339-358.

[87] Schumpp O., Gherbi H., Escoute J., Payre H., Drevon J.-J., In situ hybridization of a radioactive RNA probe on resin-embedded leg- ume root-nodule sections: a tool for observing gene expression in the rhizosphere?, Agronomie, submitted for publication.

[88] Shapiro H.M., Microbial analysis at the single-cell level: task and techniques, J. Microbiol. Methods 42 (2000) 3-16.

[89] Shishido M., Breuil C., Chanway C.P., Endophytic colonization of spruce by plant growth-promoting rhizobacteria, FEMS Microbiol. Ecol. 29 (1999) 191-196.

[90] Simon R., Priefer U., Pühler A., A broad host range mobilization system for in vivo genetic engineering: transposon mutagenesis in Gram negative bacteria, Biotechnology 1 (1983) 784-791.

[91] Smit E., Wolters A., Van Elsas J.D., Genetic stability, conjugal transfer and expression of heterologous DNA inserted into different plasmids and the genome of Pseudomonas fluorescens in soil, Rev. Microbiol. 26 (1995) 169-179.

[92] Sørensen J., Jensen L.E., Nybroe O., Soil and rhizosphere as habitats for Pseudomonas inoculants: new knowledge on distribution, activity and physiological state derived from micro-scale and single cell studies, Plant and Soil 232 (2001) 97-108.

[93] Sternberg C., Christensen B.B., Johansen T., Nielsen A.T., Andersen J.B., Givskov M., Molin S., Distribution of bacterial growth activity in flow-chamber biofilms, Appl. Environ. Microbiol. 65 (1999) 4108-4117.

[94] Stintzi A., Evans K., Meyer J.-M., Poole K., Quorum-sensing and siderophore biosynthesis in Pseudomonas aeruginosa: lasR/lasI mutant exhibit reduced pyoverdine biosynthesis, FEMS Microbiol. Lett. 166 (1998) 341-345.

[95] Suarez A., Guttler A., Stratz M., Staendner L.H., Timmis K.N., Guzman C.A., Green fluorescent protein based reporter systems for genetic analysis of bacteria including monocopy applications, Gene 196 (1997) 69-74.

[96] Thirup L., Johnesn K., Winding A., Succession of indigenous Pseudomonas spp. and Actinomycetes on barley roots affected by the antagonistic strain Pseudomonas fluorescens DR54 and the fungicide imazalil, Appl. Environ. Microbiol. 67 (2001) 11471153.

[97] Thomas J.C., Desrosiers M., St Pierre Y., Lirette P., Bisaillon J.-G., Baudet R., Villemur R., Quantitative flow cytometric detection of specific microorganisms in soil samples using rRNA targeted fluorescent probes and ethidium bromide, Cytom. 27 (1997) 224-232.

[98] Tombolini R., Unge A., Davey M.E., de Bruijn F.J., Jansson J.K., Flow cytometric and microscopic analysis of GFP-tagged Pseudomonas fluorescens bacteria, FEMS Microb. Ecol. 22 (1997) 1728.

[99] Tombolini R., Van der Gaag D.J., Gerhardson B., Jansson J.K., Colonization pattern of the biocontrol strain Pseudomonas chlororaphis MA342 on barley seeds visualized by using green fluorescent protein, Appl. Environ. Microbiol. 65 (1999) 3674-3680.

[100] Troxler J., Zala M., Natsch A., Moënne-Loccoz Y., Défago G., Autoecology of the biocontrol strain Pseudomonas fluorescens CHA 0 in the rhizosphere and inside roots at later stage of plant development, FEMS Microbiol. Ecol. 23 (1997) 119-130.

[101] Tsien R.Y., The green fluorescent protein, Ann. Rev. Biochem. 67 (1998) 509-544.

[102] Turnbull G.A., Morgan J.A.W., Whipps J.M., Saunders J.R., The role of bacterial motility in the survival and spread of Pseudomonas fluorescens in soil and in the attachment and colonization of wheat roots, FEMS Microbiol. Ecol. 36 (2001) 21-31.

[103] Unge A., Tombolini R., Mølback L., Jansson J.K., Simultaneous monitoring of cell number and metabolic activity of specific bacterial populations with a dual gfp-luxAB marker system, Appl. Environ. Microbiol. 65 (1999) 813-821.

[104] Unge A., Jansson J., Monitoring population size, activity and distribution of gfp-luxAB tagged Pseudomonas fluorescens SBW25 during colonization of wheat, Microb. Ecol. 41 (2001) 290-300.

[105] Van Elsas J.D., Dijhstra J.M., Govaert J.M., Van Veen J.A., Survival of Pseudomonas fluorescens and Bacillus subtilis introduced 
into soil of different texture in field microplots, FEMS Microbiol. Ecol. 38 (1986) 151-160.

[106] Van Elsas J.D., Van Overbeek L.S., Feldmann A.M., Dullemans A.M., de Leeuw O., Survival of genetically engineered Pseudomonas fluorescens in soil in competition with the parent strain, FEMS Microbiol. Ecol. 85 (1991) 53-64.

[107] Van Elsas J.D., Duarte G.F., Rosado A.S., Smalla K., Microbiological and molecular biological methods for monitoring microbial inoculants and their effects in the soil environment, J. Microbiol. Methods 32 (1998) 133-154.

[108] Van Loon L.C., Bakker P.A.H.M., Pieterse C.M.J., Systemic resistance induced by rhizosphere bacteria, Ann. Rev. Plant Physiol. 26 (1998) 453-483.

[109] Van Overbeek L.S., Van Veen J.A., Van Elsas J.D., Induced reporter gene activity, enhanced stress resistance and competitive ability of a genetically modified Pseudomonas fluorescens strain released into a field pot planted with wheat, Appl. Environ. Microbiol. 63 (1997) 1965-1973.

[110] Van Vuurde J.W.L., Roozen N.J.M., Comparison of immunofluorescence colony-staining in media, selective isolation on pectate medium, ELISA, and immunofluorescence cell staining for detection of Erwinia carotovora subsp. atroseptica and E. chrysanthemi in cattle manure slurry, Neth. J. Plant Path. 96 (1990) 75-89.

[111] Van Vuurde J.W.L., Van Der Wolf J.M., The use of the antibody techniques in soil, in: Alef K., Nannipieri P. (Eds.), Methods in applied soil microbiology and biochemistry, Academic Press, Inc. New York, 1995, pp. 452-457.
[112] Veal D.A., Deere D., Ferrari B., Piper J., Attfield P.V., Fluorescence staining and flow cytometry for monitoring microbial cells, J. Immunol. Methods 243 (2000) 191-210.

[113] Veena M.S., Van Vuurde J.W.L., Indirect immunofluorescence colony staining method for detecting bacterial pathogens of tomato, J. Microbiol. Methods 49 (2002) 11-17.

[114] Von Caron G.N., Stephens P.J., Hewitt C.J., Powell J.R., Badley R.A., Analysis of bacterial function by multi colour fluorescence flow cytometry and single cell sorting, J. Microbiol. Methods 42 (2000) 97-114.

[115] Waisel Y., Eshel A., Kafkafi U., Plant roots. The hidden half, Marcel Dekker (Ed.), 1991.

[116] Weller D.M., Biological control of soilborne plant pathogen in the rhizosphere with bacteria, Annu. Rev. Phytopathol. 26 (1988) 379-407

[117] Werner D., Batinic T., Feder I.S., Kosch K., Redecker D., Schulz U., Streit W., Fleischman P.V., Competitiveness of symbiotic and antagonistic soil bacteria-Development of reporter gene fusions and specific gene probes, Proceedings of the Fourth International Workshop on Plant Growth Promoting Rhizobacteria, 1996, pp. 44-48.

[118] Wilson K.J., Molecular techniques for the study of rhizobial ecology in the field, Soil Biol. Biochem. 27 (1994) 501-514.

[119] Wullings B.A., Van Beuningen A.R., Janse J.D., Akkermans A.D.L., Detection of Ralstonia solanacearum, which causes brown rot of potato, by fluorescent in situ hybridisation with $23 \mathrm{~S}$ rRNA-targeted probes, Appl. Environ. Microbiol. 64 (1998) 4546-4554. 